JEL Classification: O 33; L 10

UDC 339.137.2: 330.341.1

DOI: $10.30857 / 2415-3206.2019 .2 .3$

\section{THE ROLE OF INNOVATION IN THE DEVELOPMENT OF UKRAINE'S COMPETITIVE ECONOMY IN THE CONTEXT OF GLOBALIZATION}

\section{SHCHERBAK ${ }^{\mathbf{1}}$ D. VARENYK ${ }^{\mathbf{1}}$}

${ }^{1}$ Kyiv National University of Technologies and Design, Ukraine
Introduction. Today, innovation is becoming a strategic growth factor that can influence the structure of public production, the economic organization of society and the stabilization of the social situation in the country. The world market is constantly striving to erase physical borders between countries and establish a common economic space around the world. But at the current stage of development of Ukraine it is not fully beneficial to participate in globalization due to insufficient level of competitiveness.

Hypothesis of scientific research. It is assumed that, unlike developed and developing countries, Ukraine not only lacks effective large companies of the world level, but also suffers even more from the lack of growing, promising companies in new high-tech industries. The purpose of the article is to study the relationship between globalization and competitiveness and its peculiarities for the Ukrainian economy.

The research methodology is based on fundamental and applied research in the field of innovative growth of competitiveness of the economy in the context of globalization, materials of the state statistics service, materials of other official sources and Internet resources. In the course of the research the methods of systematization, comparative analysis, statistical methods were used.

Results: it is revealed that the main problems faced by the economy of Ukraine are mainly related to the lack of a strategy to find methods of economic development, a clear prospect of a way out of the economic crisis, which is due to political instability and low investment attractiveness.

Conclusions: It has been proved that the requirement of development of international and state economy testifies to the importance of elaboration of official policy in the sphere of competitiveness in Ukraine. Innovative development is the only prerequisite for ensuring the economic independence of Ukraine, to develop competitive advantages that will overcome the existing gap with the advanced competitive states.

Keywords: innovation; competitiveness; globalization. 
JEL Classification: O 33; L 10

УДК 339.137.2: 330.341.1

DOI: $10.30857 / 2415-3206.2019 .2 .3$

\section{РОЛЬ ІННОВАЦІЙ У СТАНОВЛЕННІ КОНКУРЕНТОСПРОМОЖНОЇ ЕКОНОМІКИ УКРАЇНИ В УМОВАХ ГЛОБАЛІЗАЦІї}

В. ЩЕРБАК ${ }^{1}$, Д. ВАРЕНИК ${ }^{1}$

${ }^{1}$ Київський наиіональний університет технологій та дизайну, Украӥна
Вступ. Сьогодні інновації стають стратегічним фактором зростання, здатним впливати на структуру суспільного виробництва, економічну організацію суспільства і стабілізацію соціальної ситуації в країні. Світовий ринок постійно прагне до стирання фізичних кордонів між країнами i встановлення єдиного економічного простору в усьому світі. Але на сьогоднішньому етапі розвитку України не в повній мірі вигідна участь в глобалізації через недостатній конкурентоспроможності.

Гіпотеза наукового дослідження. Передбачається, що на відміну від розвинених країн i країн, що розвиваються, Україна не тільки відчуває нестачу конкурентних переваг світового рівня, але ще більше страждає від відсутності зростаючих, перспективних компаній в нових високотехнологічних галузях. Метою статті $\epsilon$ дослідження взаємозв'язку глобалізації та конкурентоспроможності і іiі особливості для української економіки.

Методологією дослідження $\epsilon$ фундаментальні та прикладні дослідження в області інноваційного зростання конкурентоспроможності економіки в умовах глобалізації, дані органів служби державної статистики, матеріали інших офіційних джерел та Інтернетресурсів. В ході дослідження були використані методи систематизації, порівняльного аналізу, статистичні методи.

Результати: виявлено, що основними проблемами, 3 якими стикається економіка України, в основному, пов'язані з відсутністю стратегії щодо пошуку методів економічного розвитку, чіткого сценарію виходу 3 економічної кризи, причина якої полягає в політичній нестабільності і низької інвестиційної привабливості.

Висновки: доведено, що вимоги щодо розвитку міжнародної та національної економіки свідчать про важливість обгрунтування в Україні офіційної політики в сфері конкурентоспроможності.

Інноваційний розвиток $\epsilon$ єдиною передумовою забезпечення економічної незалежності України, створення та розвиток конкурентних переваг, що дозволить подолати існуючий розрив 3 передовими конкурентоспроможними державами. Ключові слова: інновація; конкурентоспроможність; глобалізація. 
Setting the problem. In the early years of the twenty-first century, new trends in the economic development of many countries manifested themselves. Thus, information became not only a factor of production, but also an object of labor. Therefore, the penetration of new information technologies in all production processes creates a joint impact of multiple effects on the result. In business, competitive advantages are initiated by the transition of society from the industrial and post-industrial stages of development to information, innovation and knowledge economy.

Today, innovation is becoming one of the main economic resources affecting the competitiveness of the economy. The scientific and technical level and the degree of improvement of production technologies, the use of the latest inventions and discoveries, the introduction of modern forms and methods of production and labor organization influence the level of competitiveness of the economy.

In the world practice, competitiveness assessments are carried out at the macro level, i.e. in relation to the entire national economy, as well as at the micro level, when it comes to individual sectors of the economy or enterprises exporting their products. Ukraine, as of 2019 , has risen by 5 points, that is, and so far it occupies 54th place in the rating of global competitiveness of the countries of the world according to the International Institute for Management Development in Switzerland.

In modern conditions, when the Ukrainian economy is integrated into the global economic space, has to exist in a highly competitive environment, the problem of increasing the competitiveness of national enterprises and the economy as a whole, an adequate response to the requirements of the globalizing commodity market attracts special attention.

Analysis of the latest research and the unresolved part of the problem. The active impact of innovation on competitiveness growth and research of its features in the conditions of globalization are described in detail in the works of V.M. Heyets [5], Y.B. Bazilyuk [3], J. Schumpeter [11], V. Aleksandrova [1] and A. Naumovets [8].

As noted by Y. Bazhal [2] in his paper, the obstacle to the continuous development of production is the cyclical patterns in the reproduction of the fixed capital of the country, and generate a cyclicality of its development. Economic growth of consumption stimulates the expansion of production.

V.M. Geyets [5] in his paper considers the factors of increasing competitiveness and justifies the opinion that the level of development of innovation infrastructure is one of the key factors of success for the innovative development of the country.

Y.B. Baziliuk [3] in his works considers the need to take into account changes in the mechanism of competition on the basis of innovation. 
J. Schumpeter [11] focuses on the development of innovations in competition. In his works, one can trace the trend of economic development in the form of an infinite sequence of transitions from one state of the economy to another.

B. Aleksandrova [1] and A. Naumovets [8] analyzed the impact of innovative factors on the economic development of Ukraine. In their works they have developed possible basic, optimistic and pessimistic scenarios of innovative development and formed proposals aimed at the national economy and the innovative way of development.

But despite the research, most aspects of the problem of the impact of innovation on the growth of competitiveness of the economy in the context of globalization are still not sufficiently clearly and specifically developed in the country at this stage. At the moment, the interpretation of the system of increasing the competitiveness of the country's economy is still completed. The question of the national economy in the system of increasing the competitiveness of the economy in the conditions of globalization remains debatable and unfinished.

The purpose of the article is to determine the impact of innovation on the growth of competitiveness of the Ukrainian economy and search for ways to improve it through innovative technologies in the context of globalization.

Explanation of the main research material. The basis for the "survival" of countries in the globalization process is competitiveness. The world market is now characterized by a great exacerbation of competition caused by the sharp accelerated technical development of production and increase of its efficiency. The high competitiveness of the country reflects the significant level of labor productivity and production efficiency achieved by industrial enterprises, which ensures the production of goods that are highly competitive in the world market.

Globalization covers all aspects of economic life around the world. It intensifies competition, stimulates further development of new technologies and their dissemination among countries. In this context, the growth rate of direct investment far exceeds the growth rate of world trade. Globalization can and does lead to productivity gains as a result of rationalization of production at the global level and the spread of advanced technologies, as well as competitive pressure for continuous innovation at the global level. At the same time, globalization provides an opportunity for countries to mobilize more financial resources, as investors can use broader financial instruments.

At the same time, globalization also contributes to international competition. Sometimes globalization leads to perfect competition. In fact, it is rather a matter of new competitive spheres and tougher competition in traditional markets, which is becoming possible for a single state or corporation [9]. After all, strong external competitors, who have no limits in their actions, 
join domestic competitors. The increase in the volume of uncontrolled power in the hands of a small number of economic giants operating on a global scale in the face of transnational corporations leads to distrust. The formation of unified global markets and the gradual integration of global markets into a single global market put on the agenda the issue of the emergence of global monopolies. This allows us to conclude that the processes of globalization in the form in which they are now perceived as a threat to the national interests of the Ukrainian state. Despite a certain positive trend of globalization influence, new challenges appear before the economy of the country, caused by the current state of the world economy, including the financial crisis, the need to transition to a new economy based on knowledge, innovation and information technologies.

The significant role of innovations in the global world is determined by such functions in social development:

- With the help of innovations, the achievements of human intellect and scientific and technical results are realized, the intellectualization of labor activity is promoted, and its scientific intensity is increased;

- Through innovations, the range of manufactured goods and services is expanded, their quality is improved, and contributes to the growth of the needs of each individual and society as a whole and to meeting these needs;

- Innovations make it possible to attract new productive forces into production, create goods and services with less labour, materials and energy consumption;

- Innovations serve as an incentive for entrepreneurial activity, especially in the field of small business, encourage the search and development of new goods and technologies to resist and win in competition, to occupy new market niches [4].

Thus, innovation is a prerequisite for the viability, dynamism, survival and development of human society.

The processes of development and implementation of advanced products and processes require an environment conducive to innovation and support from both the public and private sectors. For the last 20-30 years, professional economists and politicians have been actively arguing about the relative importance of various factors in creating a favorable innovation environment. In addition to macroeconomic stability, the role of institutions, education, the quality of public administration, and the availability of economic opportunities have been highlighted. In particular, significant investments in research and development, the availability of high-quality research and development institutions that can generate the basic knowledge needed to create new technologies, broad cooperation in research and technological development between universities and industry, as well as the protection of intellectual property in conjunction with a high level of competition and access to venture 
capital and financing are becoming increasingly important. Both individuals and the state play an important role in shaping the innovation environment.

For example, many economists assign a significant role in the innovation process to the education system, which is able to ensure effective participation of citizens in the economic and political life of the country. Marriage of basic knowledge limits the ability of citizens to participate in the country's development process and to be critics of government policies and politicians.

Economists note that Ukraine lacks the market-based innovation and investment financial infrastructure necessary for the commercialization of domestic innovation. As a result, scientific developments are not in demand by businesses for the production and sale of competitive high-tech products on the market. In this regard, it is necessary to pay close attention to the formation of public needs for innovative products, to work with potential consumers. The state may become one of the consumers, providing small innovative companies with state orders. However, it should not be assumed that the state can fully consume an innovative product. With most public spending on innovation, the country will not be able to reach the desired level of innovation development.

The newest technologies and knowledge form real competitive advantages and become a determining factor of economic growth. And at the moment, Ukraine's current position in the global rankings is not the best (Figure 1).

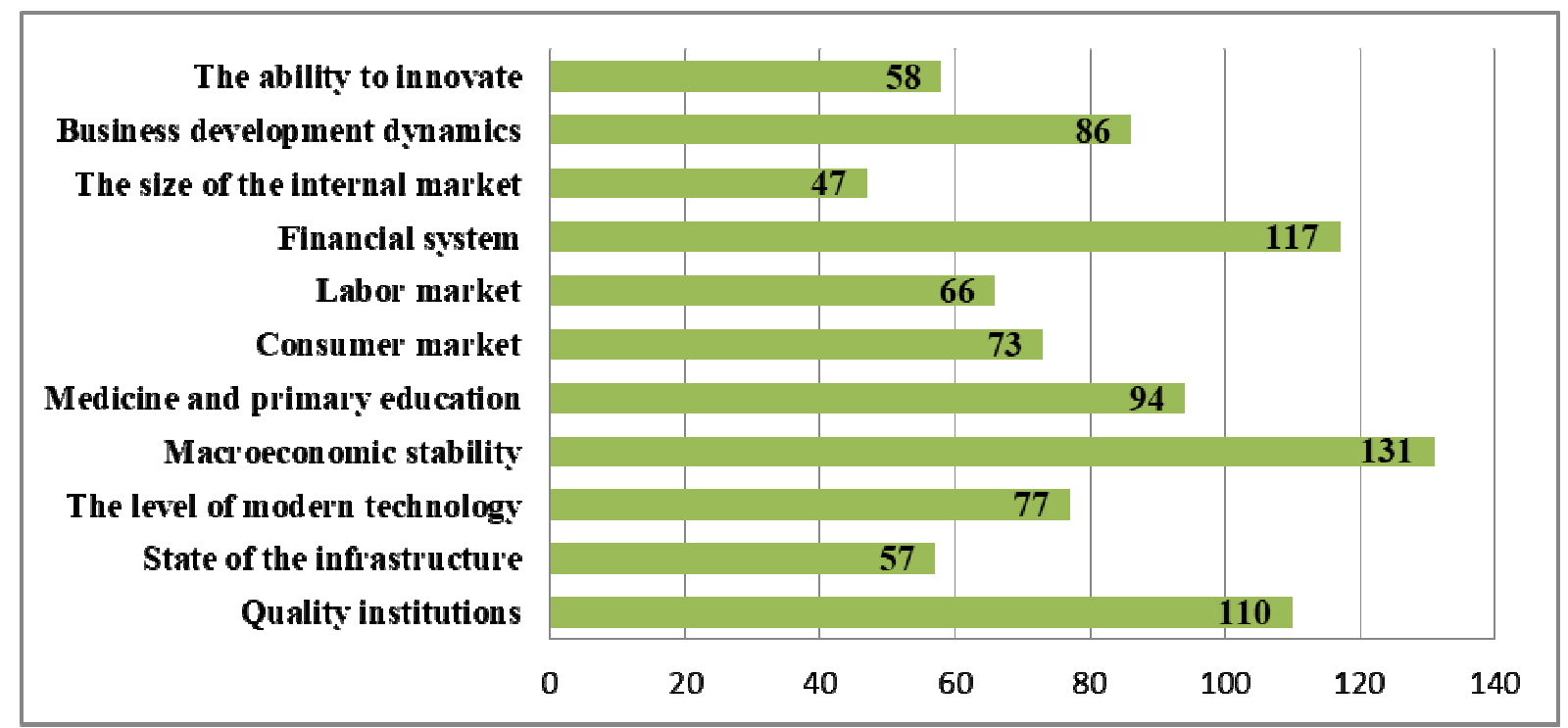

Source: [12].

Figure 1. Global Competitiveness Index of Ukraine to 2018

Particular attention should be paid to the dynamics of the national innovation economies, which reflects competition. To assess the actual competition of national innovation economies, the ratings reflecting the respective positions of the countries are the most appropriate (Table 1). 
Table 1

The World Only.org. 2019 Innovative Economy Ranking: Bloomberg Innovation Index 2019

\begin{tabular}{|c|c|c|c|c|c|c|c|c|c|}
\hline 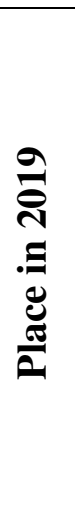 & 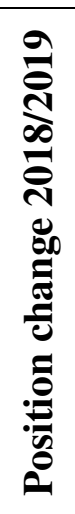 & 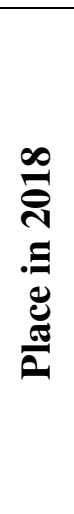 & 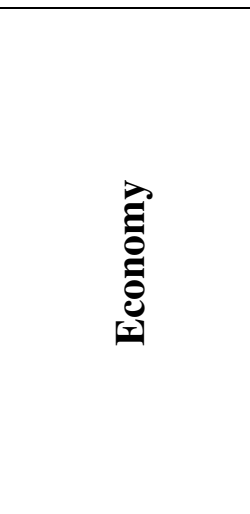 & 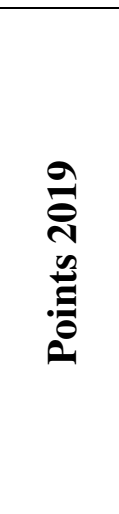 & 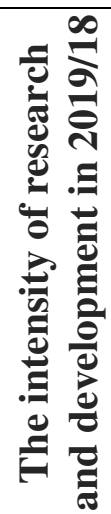 & 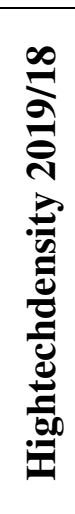 & 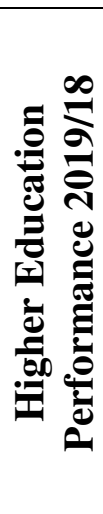 & 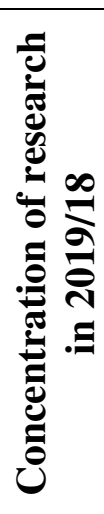 & 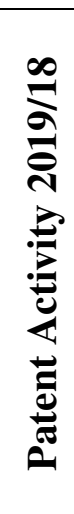 \\
\hline 1 & 0 & 1 & South Korea & 87.38 & 2 & 4 & 7 & 7 & 20 \\
\hline 2 & +2 & 4 & Germany & 87.30 & 7 & 3 & 14 & 11 & 7 \\
\hline 3 & +4 & 7 & Finland & 85.57 & 9 & 13 & 9 & 8 & 5 \\
\hline 4 & +1 & 5 & Switzerland & 85.49 & 3 & 8 & 13 & 3 & 27 \\
\hline 5 & +5 & 10 & Israel & 84.78 & 1 & 5 & 36 & 2 & 4 \\
\hline 6 & -3 & 3 & Singapore & 84.49 & 13 & 17 & 1 & 13 & 14 \\
\hline 7 & -5 & 2 & Sweden & 84.15 & 4 & 6 & 20 & 5 & 25 \\
\hline 8 & +3 & 11 & USA & 83.21 & 10 & 1 & 43 & 28 & 1 \\
\hline 9 & -3 & 6 & Japan & 81.96 & 5 & 10 & 39 & 18 & 10 \\
\hline 10 & -1 & 9 & France & 81.67 & 12 & 2 & 11 & 20 & 15 \\
\hline 51 & -3 & 48 & South Africa & 51.03 & 42 & 35 & 56 & 56 & 21 \\
\hline 52 & -9 & 43 & Tunisia & 48.92 & 50 & 41 & 49 & 43 & 55 \\
\hline 53 & -7 & 46 & Ukraine & 48.05 & 54 & 37 & 28 & 46 & 35 \\
\hline
\end{tabular}

Source: [13].

According to the rating of Bloomberg agency (see Table 1), South Korea held the first place for two years, but the position of other countries changed. For example, Germany's position was improving, while the USA was worsening. Positions of the countries were weakening a little bit and then strengthening. The first 10 places were held by about the same countries during two years. This means that the competition between the leading national innovation economies exists, and at the same time it is quite intense. However, in the short term, its effectiveness is not limited to "local" changes in the position of countries in relation to each other.

It is interesting to note that the situation in the ratings of the countries with which Ukraine has been competing in recent years is changing differently. According to the information of Bloomberg agency, among them prevail those, which are characterized by either stable (including those with some deviations) or worsening of the situation. 
Meanwhile, globalization is a pressing issue of economic reform in Ukraine, first of all, changes in the structure of commodity production, achievement of competitiveness both in the domestic and foreign markets. The first rule is mandatory: when implementing innovation economic policy, we must create favorable conditions for the formation of powerful national companies capable of successfully competing in the global economic environment. This would allow us to gradually adapt to the priority directions of the world economy development in order to take full advantage of the advantages of the international trading system.

In the conditions of fierce competition in the local and global markets, scientific achievements, transformed into various innovations, become a necessary condition for the development of individual firms, as well as for entire industries and economies [4]. In this regard, research activities become an integral component of economic practice, while the innovation process itself acquires the character of continuity and consistency.

Innovation development of Ukraine has recently become a priority area of state economic policy. This problem is increasingly becoming an object for discussion. In recent years, the country's leadership has declared the need to actively stimulate innovation.

The decisive factors determining the dynamics of innovation are technological progress and increased investment in fixed assets. These two determinants determine the growth of real national income, but in previous decades the state policy in the field of science and innovation was practically absent. At the moment, the situation in Ukraine is as follows: if not to provide a strong inflow of investments, the country will face a mass failure of outdated production assets and, as a result, final de-industrialization.

It is obvious that at present it is impossible to make a competitive product and achieve effective rates of economic growth without the introduction of hightech innovations in the production. This is explained by the fact that products that have a high innovation component have a higher value in comparison with other types of products. The market itself imposes on producers the need to create and implement high-tech innovations and increase innovation activity as a whole. The level of innovation activity directly determines the level of competitiveness, the amount of profit and, as a consequence, the financial and economic stability and stability of the enterprise.

Ukraine has actually lost most of its competitive advantages over the past decades. In case of impossibility to reproduce own technologies, practically all branches and sectors of national economy, from production to construction, have appeared depending on import of technologies. Today, almost no "domestic" goods, created entirely with the use of their own technologies, can be found. The majority of domestic enterprises have completely switched to the assembly of 
products from imported components, and some of them even do not bother to do so, and are engaged only in the fact that the imported, as a rule, from China, domestic goods.

As a result of inefficient foreign economic activity and even more inefficient economic policy in the country, the following structural reforms of the Ukrainian economy have been allowed, which has led to the decline of hightech industries, and now the main role is played by low industries [5]. The basis of Ukraine's competitiveness in the global market today are the traditional factors associated with the increase in the level of monetization of the economy, the favorable world situation in the market of low-tech goods, price competitiveness due to the low cost of labor, as well as low labor costs at the expense of curbing wage growth [6].

Let us analyze the statistics. The tables below show the statistical data of the State Statistics Committee in the field of innovation activity.

Table 2.

Introduction of innovations in industrial enterprises

\begin{tabular}{|c|c|c|c|c|c|}
\hline & 2014 & 2015 & 2016 & 2017 & 2018 \\
\hline $\begin{array}{l}\text { The share of the number of enterprises introducing } \\
\text { innovations (products and / or technological } \\
\text { processes) in the total number of industrial } \\
\text { enterprises, \% }\end{array}$ & 12,1 & 15,2 & 16,6 & 14,3 & 15,6 \\
\hline New technological processes introduced, units & 1743 & 1217 & 3489 & 1831 & 2002 \\
\hline including low-waste, resource-saving, units & 447 & 458 & 748 & 611 & 926 \\
\hline $\begin{array}{l}\text { Production of innovative types of products (goods, } \\
\text { services), units }\end{array}$ & 3661 & 3136 & 4139 & 2387 & 3843 \\
\hline of them new types of equipment, units & 1314 & 966 & 1305 & 751 & 920 \\
\hline $\begin{array}{l}\text { Share of the volume of realized innovative } \\
\text { production (goods, services) in the total volume of } \\
\text { realized production (goods, services) of industrial } \\
\text { enterprises, } \%\end{array}$ & 2,5 & 1,4 & $\begin{array}{l}\text { The } \\
\text { indicator } \\
\text { was not } \\
\text { calculated }\end{array}$ & 0,7 & 0,8 \\
\hline
\end{tabular}

Source: [14].

Table 2 shows that the share of companies that implemented innovations decreased by $1 \%$ compared to 2016, and the number of implemented new technological processes decreased by 1487 units, or $42.6 \%$. At the same time, the number of resource-saving processes increased by $23.8 \%$. The reduction of innovative types of products (goods, services) introduced into production is 296 units, or 7\%, of which new types of equipment by $29.5 \%$. The share of innovative products in the total industrial sales amounted to $0.8 \%$ as of 2018 , which is significantly less than in 2014 (2.5\%). It is obvious that the innovation activity of the Ukrainian industry is quite low as of 2018. There is a negative trend in all key indicators. 
Let us consider the dynamics of financing innovative activities of Ukrainian enterprises (Table 3).

Table 3

Sources of financing of innovative activities of industrial enterprises

\begin{tabular}{|c|c|c|c|c|c|}
\hline & \multirow[b]{2}{*}{$\begin{array}{l}\text { Innovation costs, } \\
\text { UAH mln }\end{array}$} & \multicolumn{4}{|c|}{ Including at the expense of funds } \\
\hline & & own & the state budget & $\begin{array}{l}\text { non-resident } \\
\text { investors }\end{array}$ & other sources \\
\hline 2014 & 7695,9 & 6540,3 & 344,1 & 138,7 & 672,8 \\
\hline 2015 & 13813,7 & 13427,0 & 55,1 & 58,6 & 273,0 \\
\hline 2016 & 23229,5 & 22036,0 & 179,0 & 23,4 & 991,1 \\
\hline 2017 & 9117,5 & 7704,1 & 227,3 & 107,8 & 1078,3 \\
\hline 2018 & 12180,1 & 10742,0 & 639,1 & 107,0 & 692,0 \\
\hline
\end{tabular}

Source: [14].

Table 3 shows that only UAH 639.1 million was allocated from the state budget to finance innovation activities in 2018. Strange as it may seem, the peak of the state financing of this sphere between 2014 and 2017 fell on the 2014 crisis year - UAH 344.1 million.

In 2018, 639,100,000 were allocated from the state budget to finance innovation activities of industrial enterprises. UAH, which is $0.018 \%$ of Ukraine's GDP. This indicator is very low compared to the developed countries of the world, where the main financial instrument of the state scientific and technical policy is the use of state budget funds. Its share in the total funding of scientific research in most developed countries is between 20 and 40 percent: in France it is at $40 \%$, in Germany - 35\%, the United States - 35\%, Japan - 20\%.

Assessing the state of innovation infrastructure in Ukraine and its impact on competitiveness in general, it should be noted that it is only beginning to emerge. But this process is distorted and slow, haphazard, not thoughtful. There is no systematic activity in this direction.

At the moment, Ukraine lacks the main element for activation of innovations - it is a clear and well-functioning connection between science, business and the state. So far, all three players have been working on their own. Researchers are developing what, in their opinion, is in the trend and for what there is enough funding from the budget [9]. Industry, in its turn, knows little about what innovations are developed by domestic science. And if he does, then in many cases these results are simply not interesting, because they do not meet the real needs of production. And the state continues to allocate, though small, but funds for the fact that it is not implemented in real production.

This inconsistency should be eliminated and a kind of bridge between science and industry should be established. This can only be done by the state, acting as an intermediary [7]. As you can see, this is not just about financing. There should be a competent public and private order for domestic science for 
those developments and technologies that Ukrainian production needs today. If it is realized, the science will get a new breath in the form of actual, corresponding to the market orders for scientific works, and the industry, in its turn, will be able to introduce domestic technologies, instead of spending resources on foreign ones, which are several times more expensive.

Conclusions. The results of the development of international and state economy testify to the importance of elaboration of the official policy in the sphere of competitiveness in Ukraine. Inside the country, this requirement is conditioned by structural changes.

The main problems faced by the Ukrainian economy are mainly related to the lack of a clear vision for the future of Ukraine, which is due to political instability and low investment attractiveness.

Ukraine continues to lag behind most European countries in terms of competitiveness, at the level of all elements of competitiveness, especially in the field of innovation, research and development. Therefore, the national system of education and research should be recognized as a priority and main direction of development, and should support them financially.

In a situation where Ukraine's competitiveness is a priority, the development of an innovative economy should also be a priority.

In Ukraine, the development of domestic competition policy should also be continued in order to regulate the activities of domestic monopolies, which may hinder competition.

\section{References}

1. Aleksandrova, V., Skrypnychenko, M., Fedulova, L. (2007). Prohnozuvannia vplyvu innovatsiinykh faktoriv na rozvytok ekonomiky Ukrainy [Predicting the impact of innovative factors on the development of Ukrainian economy]. Ekonomika i stanovlennia novoi systemy hospodariuvannia [Economy and the emergence of a new economic system], No. 2, P. 9-26 [in Ukrainian].

2. Bazhal, Yu.M. (2000). Innovatsiina teoriia ekonomichnoho rozvytku: M. Tuhan-Baranovskyi, J. Schumpeter i problemy perekhidnoi ekonomiky Ukrainy [Innovative Theory of Economic Development: M. Tugan-Baranovsky, J. Schumpeter and Problems of the Transition Economy of Ukraine]. Naukovi zapysky [Scientific Notes], Vol. 18. Ekonomichni nauky [Economic Sciences], P. 3-7 [in Ukrainian].

3. Bazyliuk, Ya.V.

Konkurentospromozhnist

\section{Література}

1. Александрова В. Прогнозування впливу інноваційних факторів на розвиток економіки України / В. Александрова, М. Скрипниченко, Л. Федулова // Економіка i становлення нової системи господарювання. - 2007. - № 2. - С. 9 26.

2. Бажал Ю. М. Інноваційна теорія економічного розвитку: М. ТуганБарановський, Й. Шумпетер i проблеми перехідної економіки України / Ю. Бажал // Наукові записки. - 2000. - Т. 18. Економічні науки. C. 3-7.

3. Базилюк Я. В. Конкурентоспроможність національної економіки: сутність 
ekonomiky: sutnist ta umovy zabezpechennia: monohrafiia [Competitiveness of the National Economy: Essence and Conditions of Supply: Monograph]. Kyiv: NISD. 132 p. [in Ukrainian].

4. Buleev, I.P. (2012). Opyt strukturirovaniia promyshlennosti razvitykh stran i vozmozhnost ego ispolzovaniia $v$ Ukraine [The experience of structuring the industry of developed countries and the possibility of its use in Ukraine]. Stratehiia i mekhanizmy rehuliuvannia promyslovoho rozvytku: zb. nauk. prats [Strategy and mechanisms of regulation of industrial development: a collection of scientific works]. Donetsk: IEP NAN Ukraine. P. 3-29 [in Russian]. 5. Heiets, V.M., Fedulova, L.I. (2007). Natsionalna innovatsiina systema:zarubizhnyi dosvid, stan $\mathrm{v}$ Ukraini: analitychni materialy do parlamentskykh slukhan [National innovation system: foreign experience, state of affairs in Ukraine: analytical materials for parliamentary hearings]. Kyiv: Institute of Economics and Forecasting of NAS of Ukraine. 184 p. [in Ukrainian].

6. Deliagin, M.G. (2001). Novye problemy i vozmozhnosti obespecheniia

konkurentosposobnosti $\mathrm{v}$ usloviiakh globalizatcii [New challenges and opportunities to ensure competitiveness in the context of globalization]. Prometei: reh. $z b$. nauk. prats $\mathrm{z}$ ekonomiky [Prometheus: a regional compilation of scientific papers on economics]. Donetsk: Yuho-Vostok. Vol. 4, P. 37-56 [in Russian].

7. Zhykhor, O.B. (2009). Rol teorii innovatsii ta innovatsiinoho rozvytku u formuvanni rehionalnoi innovatsiinoi polityky [The role of innovation theory and innovation development in the formation of regional innovation policy]. Ekonomika promyslovosti [Economics of Industry], No. 1, P. 132-137 [in Ukrainian].

8. Naumovets, A.H. (2010). Vid fundamentalnykh doslidzhen do komertsializatsii rezultativ: dosvid i zavdannia NAN Ukrainy [From basic research to commercialization of results: experience and tasks of NAS of Ukraine]. Nauka ta naukoznavstvo [Science and science knowledge], No. 2, P. 21-31 [in Ukrainian].

9. Nikolaev, A. (2001). Innovatcionnoe razvitie i innovatcionnaia kultura [Innovative development and innovative culture]. Problemy teorii i praktiki та умови забезпечення: монографія / Я. В. Базилюк. - К.: НІСД, 2002. $132 \mathrm{c}$.

4. Булеев И. П.

Опыт структурирования промышленности развитых стран и возможность его использования в Украине / И. П. Булеев // Стратегія і механізми регулювання промислового розвитку: зб. наук. праць / IЕП НАН України. Донецьк, 2012. - С. 3-29.

5. Геєць В. М.

Національна інноваційна система:зарубіжний досвід, стан в Україні: аналітичні матеріали до парламентських слухань / В. М. Геєць, Л. І. Федулова. - К.: Ін-т економіки та прогнозування НАН України, 2007. - 184 с.

6. Делягин М. Г. Новые проблемы и возможности обеспечения конкурентоспособности в условиях глобализации / М.Г.Делягин // Прометей: рег. зб. наук. праць 3 економіки. - Донецьк: Юго-Восток, 2001. - Вип. 4. - С. 37-56.

7. Жихор О. Б. Роль теорії інновацій та інноваційного розвитку у формуванні регіональної інноваційної політики / О. Б. Жихор // Економіка промисловості. - 2009. - № 1. C. $132-137$.

8. Наумовець А. Г.

Від фундаментальних досліджень до комерціалізації результатів: досвід i завдання НАН України / А. Г. Наумовець // Наука та наукознавство. - 2010. - № 2. - С. 2131.

9. Николаев А. Инновационное развитие и инновационная культура / А. Николаев // Проблемы теории и 
upravleniia [Problems of management theory and practice], No. 5, P. 57-63 [in Russian].

10. Rozhkova, T.S. (2012). Innovatsiini skladovi ekonomichnoho rozvytku krainy [Innovative components of economic development of the country]. Suchasni pytannia ekonomiky i prava [Modern issues of economy and law], No. 1, P. 57-63 [in Ukrainian].

11. Schumpeter, J. (1982). Teoriia ekonomicheskogo razvitiia (Issledovanie predprinimatelskoi pribyli, kapitala, kredita, protcenta i tcikla koniunktury) [Theory of economic development (Study of entrepreneurial profit, capital, credit, interest and the business cycle)]. Moscow: Progress. 454 p. [in Russian].

12. Ukraina zaniala 83-e mesto $\mathrm{v}$ reitinge globalnoi konkurentosposobnosti, podniavshis na shest pozitcii [Ukraine took 83rd place in the ranking of global competitiveness, rising by six positions]. Retrieved from: https://gordonua.com/ news/money/ukraina-zanyala-83-e-mesto-v-reytin ge-globalnoy-konkurentosposobnosti-podnyav shis-na-shest-poziciy-432910.html [in Russian].

13. Reiting innovatcionnykh ekonomik - 2019: Iuzhnaia Koreia lidiruet shest let [Innovation Economy Ranking 2019: South Korea Leads Six Years]. Retrieved from: https://theworldonly.org/ rejting-innovatsionnyh-ekonomik-2019 [in Russian].

14. Derzhavna sluzhba statystyky Ukrainy [State Statistics Service of Ukraine]. Retrieved from: http://ukrstat.gov.ua [in Ukrainian]. практики управления. - 2001. - № 5. C. 57-63.

10. Рожкова Т. С. Інноваційні складові економічного розвитку країни / Т. С. Рожкова // Сучасні питання економіки і права. - 2012. - № 1. C. $57-63$.

11. Шумпетер Й.

Теория экономического развития (Исследование предпринимательской прибыли, капитала, кредита, процента и цикла конъюнктуры) / Й. Шумпетер. - М.: Прогресс, 1982. - 454 с.

12. Украина заняла 83-е место в рейтинге глобальной конкурентоспособности, поднявшись на шесть позиций [Электронный ресурс]. Режим доступа: https://gordonua.com/ news/money/ukraina-zanyala-83-e-mesto -v-reytinge-globalnoy-konkurentosposob nosti-podnyavshis-na-shest-poziciy432910.html.

13. Рейтинг инновационных экономик - 2019: Южная Корея лидирует шесть лет [Электронный ресурс]. - Режим доступа: https://theworldonly.org/ rejting-innovatsionnyh-ekonomik-2019.

14. Державна служба статистики України [Електронний ресурс]. Режим доступу: http://ukrstat.gov.ua. 